Игор Д. ПЕРИШИЋ Институт за књижевност и уметност Београд
Оригинални научни рад

Примљен: 30. 11. 2020.

Прихваћен: 25. 2. 2021.

\title{
КЊИЖЕВНИ КРИТИЧАР СЛОБОДАН ЈОВАНОВИЋ КАО ПИСАЦ ИСТОРИЈЕ СРПСКЕ КУЛТУРЕ
}

\begin{abstract}
У полихисторском делу Слободана Јовановића, помало скрајнуто али не и неважно место заузимају његови књижевнокритички радови којима је заправо и ступио у јавни живот српске културе. Као књижевни критичар, Слободан Јовановић увек обраћа пажњу на шири културно-историјски контекст књижевног дела. Његова критика обележена је својеврсним културним просветитељством, где се истиче помало утилитарна природа књижевности као духовног поља у којем се имају остварити шири циљеви. Писане изузетно јасним и разговетним, београдским стилом, чији је он - уз Јована Скерлића и Богдана Поповића - један од утемељивача, његове књижевне критике се тако, у складу са савременим методолошким полазиштима поетике културе, могу сматрати фрагментарним прилозима за историју српске културе.

Кључне речи: српска књижевна критика, културна идеологија, културна историја, Слободан Јовановић.
\end{abstract}

Међу не тако многобројним српским полихисторима, који су својим разуђеним делом оставили велики траг у историји српске културе, Мило Ломпар у књизи Полихисторска истраживања посебно место даје Слободану Јовановићу. ${ }^{1}$ Сматрајући да је фигура полихистора у свим временима са собом носила начело субверзивности као отпора монистичком мишљењу, што има резултовати или радикалном антисистемском егзистенцијом, односно практиковањем деконструктивног културолошког писма, или научним/уметничким хабитусом који ће тежити либерално-хуманистичкој синтези, Ломпар ће Јовановића доживети у овом другом смислу. Као полихистор са израженом

\footnotetext{
*perisigor@gmail.com

${ }^{1}$ Савременици и пријатељи говоре о ренесансном духу Слободана Јовановића, што би било друго име полихисторства. Чувени критичар Бранко Лазаревић сведочи да је на Крфу 1916. године, где су заједно били на служби у српској војсци, први пут осетио колико је Јовановић био ренесансна личност: „Његово интересовање је невероватно великих размера. Нисам могао, уопште, да видим да ли што постоји што га свестрано не занима” (Лазаревић 1991: 832).
} 
радном етиком, ${ }^{2}$ Јовановић ће у свим својим многобројним делатностима тежити целосном мишљењу, које је дакако отворено за различите дисциплинарне увиде, али са друге стране, чином избора, укорењено у матичну културу која се у таквој оптици јавља као једина, самосвесно одабрана универзалија. Помало скрајнут, али не и неважан, чак можда и један од магистралних токова његовог полихисторства јесте књижевни рад, којим је, по повратку са студија права из Женеве и Париза, и ушао у јавни живот 1892. године као позоришни и књижевни критичар, да би касније пре свега у портретима захватао општу књижевнокултурну али и историјско-политичку климу једног времена.

У односу према књижевности као пре свега друштвеној, широј појави, Слободан Јовановић је, према Ломпару, онда морао да у свом полихисторском „несвесном” при анализи и критичким приказима књижевних дела увек на уму има културну контекстуализацију (Ломпар 2016: 17). Као сапутник целе једне генерације српских модернистичких писаца (Милош Црњански, Растко Петровић, Станислав Винавер, Тодор Манојловић, Момчило Настасијевић), он је с њима делио уважавање западних културних вредности. С друге стране, подразумевало се и да „еминентно западни нараштај” развија елементе самосвести који су водили ка „стварању вредности и унутар традиције: отуд су они откривали средњовековну прошлост, осамнаестовековне полихистоpe, нови сјај романтичара" (Ломпар 2016: 35). Укратко речено, у Јовановићевом полихисторском сензибилитету постојало је изоштрено естетско чуло „отворено и за авангардне и за традиционалне вредности” (Ломпар 2016: 36), и за европску и националну културу, како би се и дало очекивати од једног теоријског либерала са понешто, по већинском мишљењу, конзервативним погледима на поједине уметничке и културне праксе.

Примера ради, Јовановић је почесто писао неповољно о Стерији, са иронијским жаокама када се чувени Вршчанин „спусти” испод нивоа онога што је код њега највише ценио. Српски мислилац је више поштовао Стеријина „жалосна позорја”, као год и историјске трагедије других писаца из 19. века које су данас скоро заборављене. „Посебно је био осетљив на водвиљски смех и површни хумор подређен дневним политичким потребама", закључио је Миливој Ненин (2008: 184). Такође, према Нениновом мишљењу, Јовановић није показивао довољно флексибилности према авангардној уметности, али то се дешавало у каснијим годинама, када је књижевну критику објављивао спорадично и више се концентрисао на писање портрета личних пријатеља и писаца из своје генерације. С друге стране, иако унеколико оштар у односу према смеху, пишући о Браниславу Нушићу није штедео речи хвале. Говорећи 1900. године о три пишчева комада различитих жанрова, Слободан Јовановић тврди да би се могло „без претјеривања рећи, да он сам вриједи колико читаво коло драмских књижевника" (Јовановић 1991а: 881). Ипак, и

2 Уз делимичну употребу савремене англицизоване лексике могло би се казати да је Јовановић био самопрегорни радохолик, нежења који је готово био без приватног живота. Живорад Стојковић сматра да је библиографија његових радова: „пре каталог издања каквог института друштвених наука, но попис животног дела једног човека” (Стојковић 1963: 5). 
када је, са данашње тачке гледишта, потценио значај неких стваралаца и прехвалио умеће других, никада то није било због личних идиосинкразија, већ због тога што је његов научнички хабитус водио рачуна о представи културе у историјском контексту.

Међутим, на став Јовановића према авангардним или уопште модернизацијским тенденцијама у литератури могуће је гледати и из мало другачијег угла; из перспективе уравнотеженог приступа свим поетикама и књижевним поступцима. У енциклопедијском погледу на књижевно дело Слободана Јовановића, где се зашло у све рукавце његовог разуђеног писања, Бојан Јовић закључује да је наш критичар имао:

[...] наглашен осећај за оно што је битно, макар то и не било по његовом личном укусу. У приступу критици, у свом је суду уравнотежен и обухватан, настојећи да читаоцу представи најважније видове појава о којима пише, како њихове лоше тако и њихове добре стране. Без обзира што високо цени композициону, то јест рационалну, страну књижевног дела, код Јовановића преовлађује став супротстављања догматизму, обрасцима и маниризмима свих врста, и наглашавање изворног књижевног и читалачког доживљаја - само оно што је искрено проживљено и изазива емоцију заправо је вредно пажње (Јовић 2020: 405-406).

На основу овакве опште оцене, онда постаје очито да је Јовановић понекад био неправедно оптуживан за потцењивање одвећ радикалних поетика, посебно књижевне авангарде. Према Јовићевом мишљењу, српски критичар био је ипак пријемчив за модернистичко-авангардистичка кретања, отворио је странице Гласника за остварења најважнијих, али ипак и „најумеренијих” представника нове књижевне осећајности: Милоша Црњанског, Растка Петровића, Сибета Миличића, Светислава Стефановића. Са друге стране, његов ,уравнотежени и толерантни приступ” у критици и уређивачкој политици према књижевним савременицима и новим појавама „имао је и повратно дејство - чак и када су критички интонирани, искази 'младих' обележени су поштовањем према Слободану Јовановићу” (Јовић 2020: 403).

Када се ракурс помери ка општим културним питањима, оправдана је тврдња да је Јовановић био близак схватању како књижевност треба да „претходи култури и националном прогресу. Уосталом, то је став читавог његовог нараштаја" (Лудошки 2008: 6). Како је сажето формулисао Предраг Палавестра у својој Историји српске къижевне критике, добрано надахнуте Јовановићевим стилом, он никада није био чисти књижевни критичар, него „историчар са изразито развијеним критичким смислом за разумевање духовног и културног контекста епохе о којој говори" (Палавестра 2008: 729). Двоструки поглед или свест о контексту Јовановићева је темељна карактеристика: када пише и позоришну и књижевну критику, сматра Миливој Ненин, српски мислилац „има у виду и појединачну представу или књижевни текст, али има у виду и место свега тога у култури Срба” (Ненин 2008: 183). Критичар полихисторског образовања и интегралистичког кова морао је увек да води рачуна - материјалистичким језиком казано - о целини културне производње народа којем је припадао. 
Свест о културној мисији књижевности у контексту широких Јовановићевих интересовања са методолошког становишта могла би се довести у везу са каснијим теоријским правцем названим поетика културе. Корпус културе, на основу којег се формирају студије културе, у англоамеричком схватању обухвата све што спада у људска знања, делатности, забаву, навике, институције, разне материјалне односе, али и праксе означавања и репрезентације. У поетици културе све уметности и научне дисциплине схватају се као одређене културне институције, специфична поља у оквиру културне продукције (в. Перишић 2007: 201-202). Интегралистичко схватање културе Слободана Јовановића - у којем подједнако важно место има и материјалистички њен део - ваљало би у неком опсежнијем истраживању посматрати као претечу овог теоријског правца који се, на терену интердисциплинарно схваћене историографске струке, назива још и новим историзмом.

Слободан Јовановић је у наслову овог рада назван писием историје српске културе, а не њеним историчарем, управо због тога што је, поред осталог, био један од најбољих српских књижевника, ако се књижевност не схвата само као писање фикције. Уз Јована Скерлића, Богдана Поповића и друге ауторе окупљене око Српског кюижевног гласника, српски мисилац био је творац чувеног београдског стила, у којем је дошло до „срећног споја западне културе и наше традиционалне културе” (Јовичић 2011: 95). Први талас јасног, углађеног и отменог београдског језика и стила, обележили су његови полихисторски радови, да би аутор временом тежио још већем постизању „реченичке смирености, прецизности и згуснутије употребе чињеница” (Самарџић 1990: 674). Бивајући и сам један од најбољих стилиста српске историографије, Радован Самарџић је најпозванији да примети како је Јовановић имао необичну прилагодљивост стила „који је сав у употреби теза и антитеза, у освајању читаоца парадоксалним изненађењима, у обртима који су код њега не само украс него и средство продора до дна истине” (Самарџић 1990: 697).

У монографији која се бави Слободаном Јовановићем као књижевним критичарем, Наталија Лудошки доноси добар мали каталог ауторових стилских особености:

Чињеницу да је за Слободана Јовановића критика висококреативни чин могуће је поткрепити аргументима о стилској беспрекорности његових састава, обиљу финих досетки, необичних поређења, често хуморно интонираним опаскама, памфлетском рескошћу судова, доброј композицији текста. Писане углађеним и отменим изразом - београдским стилом, његове критике су разумљиве (и намењене, уосталом) најширем кругу читалаца (Лудошки 2008: 9).

Међутим, није баш увек, барем у младим данима, критика Слободана Јовановића била тако углађена, већ веома оштра у неким моментима, што и не мора да буде у супротности. Пишући о Јовановићевим раним радовима, теоретичар књижевности Иво Тартаља сматра да у њима има „младалачке жустрине” и „грозног цинизма, до инвективе” (Тартаља 1998: 743). Ствар је у томе што се наш критичар у зрелијим годинама мало бавио тзв. дневном критиком, која увек захтева другачији, директнији и понекад жешћи тон. 
Ипак, и у дужим књижевним огледима и портретима, није га напуштао иронично-цинички дух, као залог општег интелектуалног либерализма који почива на духу скепсе. Доводећи у питање мњење о Слободану Јовановићу као неутралном, равнодушном посматрачу, Душан Иванић у њему напослетку види и сатирика:

Јовановић је био изузетно оштар кад нешто у начелу негативно представља као да је позитивно, или кад се оно што је вредно преокрене у безвредно и супротно првобитном смислу: у овом историчару, правном писцу и критичару - аналитичару књижевних дела имали смо заправо сатирика, човека који дели лице и наличје, истину и њену маску, јер га је дубоко познавање живота учинило скептичним према свим људским напорима (Иванић 2006: 49).

Као што је то био случај у историографским списима, врхунац књижевнокритичке делатности Слободан Јовановић достиже у жанру портрета. У овом жанру долази до изражаја с једне стране способност културолошког уопштавања, сагледавање мисије конкретног писца у историји српске култуpe, док се с друге стране, у беспрекорној равнотежи, откривају психолошко свесно и несвесно које стоје у подлози индивидуалног стварања, као и смисао за живописан биографски детаљ, духовито лично сведочанство о предмету у скоро по романескном или драмском принципу вешто склопљеној нарацији. Пишући 1927. године о Слободану Јовановићу као политичком и културном историчару српског народа, Сима Пандуровић се задржава на његовом интересовању за психологију личности и психологију колектива. Поред осталог зато што је успевао да у портретима убедљиво пренесе спознају да су „сва начела, све идеје и све теорије нераздељиве од психологије личности која их инаугурише и заступа" (Пандуровић 1991: 830) - то чини од Јовановића једног од најбољих писаца српске психолошко-историографске прозе.

У том смислу, антологијски је портрет Љубомира Недића у којем Слободан Јовановић надахнуто анализира књижевну критику која је писана са свешћу о уклапању у општу историју књижевности и културе, уз живу контекстуализацију и преплитање са политичком историјом Србије. Портрет је написан са израженим компаративним сензибилитетом за положај и предметног и властитог текста у замишљеној културној историји Европе, и са нарочитом пажњом усмереном ка немачкој, француској и енглеској култури које су и критичар и метакритичар веома добро познавали. У интегралистичком критичком пориву, код Јовановића добијамо, нарочито у случају писаца с којима је пријатељевао, готово вербалним средствима дочаране фотографске портрете у којима су прецизно истакнуте личне карактеристике:

Поред све своје болести, Недић је имао скоро младићску живост погледа и хитрину покрета. Имао је лепе црне очи, које су гледале са паметном радозналошћу и срдачном непосредношћу. Руке му нису никако мировале, и поред све нервозности и расклиматаности његових покрета, у њима се осећала извесна брзина и одсечност. Његов је говор био жив, а његово расположење ведро: он је изгледао као болесник, а понашао се као здрав човек (Јовановић 1991а: 677). 
Портретишући Недића као полемичара, Јовановић и ту користи прилику да изнесе своје интегралистичко схватање уметности и културе. Наиме, у жанру полемике највише на видело излази контекстуална природа књижевнокритичког чина, а занимање публике за књижевне „свађе”, које веома личе на политичке, још једном потврђује да је и политика део културе, као што свакако важи и обратно. У портретисању овог поља Недићеве активности, увешће се и лична нота, на основу које Јовановић опет доказује вештину књижевног уопштавања изузетно живописне сликовитости:

Он ће вероватно остати запамћен у том ставу борца, као један пусти витез или мускетар критике, који је у нашу књижевност упао из небуха, заметнуо кавгу на све стране, и с неколико хитрих удара очистио за час терен око себе (Јовановић 1991а: 699).

Способност културолошко-историјске контекстуализације не спречава Јовановића за невероватно прецизне увиде у иманентној анализи, али који се увек односе на целину дела, а не на микросегменте. У једном кратком напису о Његошу из 1925. године, краћем од једне странице (а овде ће бити цитирана половина тог текста), он у неколико реченица успева да ухвати онај и данас актуелни проблем Горског вијенияа, сукоб општечовечанског и морала једне конкретне друштвене заједнице, у чему се заправо и огледа свевремена, античка трагика овога дела. Управо због нареченог у левичарским политички коректним књижевно-идеолошким круговима јављају се позиви за преиспитивање статуса Горског вијенца као канонског дела српске књижевности. Речи Слободана Јовановића могле би и у тој расправи послужити као убедљив контрааргумент тези да прошле епохе треба саображавати данашњој:

Горски вијенаи је чудновата мешавина варварства и душевности. То је стихована хроника једнога покоља неверника који опомиње на Вартоломејску ноћ, - али та хроника пуна је јада и плача, - и то не оних које убијају, него онога који убија. Владика Данило, приређивач покоља, кука над њиме као над својом личном несрећом; то за њега није никакав триумф, него тешка жртва од које његова душа остаје неутешна и болна. Он пристаје на покољ као на једну свирепу дужност коју му је судбина наметнула, - следујући, као у неком месечарском заносу, једноме загонетном налогу озго који нити разуме нити одобрава потпуно. Највиша места Горског вијенца одржана су у тој атмосфери недокучности историјске судбине и необјашњивости човекових дужности. То је исти онај дах фатума који се осећа код старих грчких трагичара, - и у Његошу има нечега од Есхила (Јовановић 1991a: 789).

Дакле, и када пређе на иманентну анализу, Јовановић се труди да такво испитивање буде у функцији осветљавања културне мисије коју дело потенцијално остварује или, у овом случају, реч је о увиду у значај дела у целокупној историји светске књижевности. Тиме се успоставља извесна равнотежа текста и контекста, као што се и у самој иманентној анализи позитивно вреднује ако писац постигне склад у поштовању логике одабраног жанра или стила у односу на садржину написаног. Да би било релевантно и изван матичне културе, књижевно дело треба да ухвати нешто и од епистемског и од универзалног културноисторијског тока. 
У написима о светској књижевности, када је у најбољој форми, код српског критичара долази до изражаја способност да једном метафоричко-епифанијском речју проникне до суштине и пишчевог проседеа и писца као личности. Не би било претерано рећи да у овим огледима има скоро надљудског напона у објавама продорних увида. Понекад су ти увиди обликовани као захуктале стреле које вибрирају право ка мети. Примера ради, у једној веома густој, али не и претрпаној полуреченици, увиђа се шта је главна особина дела Џонатана Свифта:

Дивљина Свифтове сатире, беснило његове мржње, његова патолошка гадљивост према човеку и свему што је људско, грозотни реализам његових мизантропских снова и алегорија, који опомиње на једног Дантеа безбожног и прозаичног [...] (Јовановић 1991а: 693).

Вештина речитог а заправо концизног уопштавања може се пратити у већини огледа о светској књижевности. У неким случајевима, као у напису о Волтеровом Кандиду, са великом ерудицијом - која се никада на открива на први поглед као код свих културолошких џентлмена - Јовановић духовито и живо представља културно-историјски контекст дела, да би намах на њега бацио ново светло:

Кандид је написан онако као што се разговарало у салонима XVIII века, и докле га читамо, нама не изилази пред очи слика једног књижевника, који сам у својој соби, с напором, склапа један роман, психолошки, социолошки, историјски, експериментални, или какав други; већ нам излази пред очи слика једног господина који, у отменом друштву, сасвим неусиљено, ради забаве своје и својих слушалаца, казује једну анегдоту (Јовановић 1991б: 480-481).

Генерално гледано, када је писао о европским књижевницима српски мислилац је, попут свог великог претходника Доситеја Обрадовића, био културни просветитељ, трудећи се да у српску културу унесе нова знања, којима се напајао на европским изворима, те да делује умерено еманципаторски. ${ }^{3}$ При томе, како је приметио Миловој Ненин: „И када пише о европским пи сцима Слободан Јовановић има првенствено у виду српску културу, али и кад пише о српским писцима има у виду Европу" (Ненин 2008: 186). Европеизација коју на уму има наш полихистор пре свега служи сврси да се поставе виши стандарди за српску културу, јер се у сталном подизању културолошке лествице огледа културолошки патриотизам европског кова.

У постхумно објављеном спису Један прилог за проучавање српског националног карактера (публикован у Канади 1964, писан 1957. године, где јасно говори о појму културног обрасца и појму полуинтелектуалца, в. Милосављевић 2012), Слободан Јовановић доноси синтезу свог погледа на кул-

\footnotetext{
${ }^{3}$ Примера ради, неки од Јовановићевих закључака у анализи женских ликова у драмама Хенрика Ибзена могли би се назвати еманципаторским у протофеминистичком смислу, иако их пише још у 19. веку (1894. године): „У неку руку, оне одступају од оног женског типа који је постао конвенционалан. Онима који имају маште те се жене могу учинити још претече жене двадесетог века, жене ослобођене што ће рећи жене с човеком потпуно изједначене, и сувише, жене која је потчинила човека исто онако, као што је вековима човек њу потчињавао“ (Јовановић 1991б: 508-509).
} 
туру као на интегралистичко поље у којем се огледају све друге националне и духовне и материјалне делатности. Писац у овом огледу експлицитно тврди да је култура „шири појам и од науке, и од уметности, и од политике” (Јовановић 1991б: 566). Било је у српској историји знаменитих политичара који нису били баш „на ти” са културом, и то им је, иронично примећује Јовановић, чак узимано као предност, јер се тако, наводно, нису удаљавали од народа. И неки књижевници су се поводили за принципима барбарогенија и боемског живота, не марећи много за културно образовање. Наука, сама по себи, такође не гарантује културну самосвест свог практиканта, јер се научници понекад развијају одвећ у правцу крутог интелектуализма, занемарујући културу духа. Ни политика, ни уметност, ни наука, узете појединачно нису, дакле, довољне за формирање културног човека:

Културни човек није једностран. Он негује и своју интелектуалност, и своју осећајност, и своју моралност. Сагласност коју тежи одржати између тих разноврсних елемената, огледа се у целом његовом начину живота, у целој његовој личности. Његова филозофија живота прешла му је у нарав (Јовановић 1991б: 566).

За индивидуалног културног човека неопходан је и општи културни образац, о којем је Јовановић са за њега необичном страшћу писао, али тај образац свакако не би требало да буде хегемон и уједначавајући, тј. он не би смео да буде производ никаквог културолошког инжењеринга, већ само артикулисани и у сферу идеја подигнути екстракт најбољих постигнућа једног народа. Тек тада настаје здрава утакмица различитих култура:

Али и онда када се не налази у утакмици с другим националним групама, једна нација ваља да негује своју културу. Чим се човек уздигне нешто мало изнад националног егоизма, њему постаје јасно, да нација сама собом не представља оно што се у филозофији назива „вредност”. Вредност јој могу дати само општи културни идеали, којима би се она ставила у службу (Јовановић 1991б: 572-573).

У залагању Слободана Јовановића за формирање културног обрасца огледа се једно од његових најдубљих практичних сазнања као историчара српске културе. То представља подршку успостављању својеврсног општег духовног канона, отвореног за нове појединачне доприносе, који ће претрајавати каткад упоредо а понекад „изнад” политичког и националног поља. Задатак политичког и националног јесте подршка оном културном као духовно надређеном. „Општи културни идеали”, што би била садржина културног обрасца, јесу оне вредности - и то је позна манифестна објава и духовни тестамент Слободана Јовановића - због којих вреди деловати у свим областима културе као кровног имена за човекова подузећа у орбити идеја или у свету у којем се виде конкретни материјални резултати тих идеја. 


\section{ИЗВОРИ}

Јовановић 1991а: С. Јовановић, Из историје и књижевности I, Београд: БИГЗ, Југославијапублик, СКЗ.

Јовановић 1991б: С. Јовановић, Из историје и књижевности II, Београд: БИГЗ, Југославијапублик, СКЗ.

\section{ЛИТЕРАТУРА}

Иванић 2006: Д. Иванић, Цинизам „равнодушног посматрача”, у: С. Мавреновић и др. (прир.), Слободан Јовановић - живот и дело, Београд: Српска либерална странка, 46-52.

Јовичић 2011: М. Јовичић, Слободан Јовановић: илустрована монографија, Београд: Службени гласник, Фонд „Миодраг Јовичић”.

Јовић 2020: Б. Јовић, (Ре)конструкција једног читалачког искуства: Поетика књижевности Слободана Јовановића, y: К. Чавошки, А. Костић (ур.), Слободан Јовановић: поводом 150 година од рођења, Београд: САНУ, 391-407.

Лазаревић 1991: Б. Лазаревић, Лик Слободана Јовановића, y: С. Јовановић, Из историје и књижевности II, Београд: БИГЗ, Југославијапублик, СК3, 832-834.

Ломпар 2016: М. Ломпар, Полихисторска истраживања, Београд: Catena mundi.

Лудошки 2008: Н. Лудошки, Слободан Јовановић као књижевни критичар, Нови Сад: „Венцловић”.

Милосављевић 2012: Б. Милосављевић, Културни образац и појам полуинтелектуалца, Београд: Култура, бр. 137, 127-143.

Ненин 2008: М. Ненин, Прилог историји српске књижевне критике, $y$ : Н. Лудошки, Слободан Јовановић као књижевни критичар, Нови Сад: „Венцловић”, 183-186.

Палавестра 2008: П. Палавестра, Историја српске књижевне критике 1768 2007, Нови Сад: Матица српска.

Пандуровић 1991: С. Пандуровић, Слободан Јовановић, y: С. Јовановић, Из историје и књижевности II, Београд: БИГЗ, Југославијапублик, СКЗ, 829-832.

Перишић 2007: И. Перишић, Гола прича: Аутопоетика и историја у „Гробници за Бориса Давидовича” Данила Киша, „Новом Јерусалиму” Борислава Пекића и „Фами о бищиклистима” Светислава Басаре, Београд: Плато, Институт за књижевност и уметност.

Самарџић 1990: Р. Самарџић, Дело и писац, у: С. Јовановић, Из историје и књижевности II, Београд: БИГЗ, Југославијапублик, СКЗ, 673-718. 
Стојковић 1963: Ж. Стојковић, Уместо предговора, y: С. Јовановић, Портрети из историје и књижевности, Нови Сад, Београд: Матица српска, Српска књижевна задруга, 5-18.

Тартаља 1998: И. Тартаља, Никада прештампани, рани радови Слободана Јовановића, y: М. Јовичић (ур.), Слободан Јовановић - личност и дело, Београд: САНУ. 741-747.

\author{
Igor D. Perišić
}

\title{
LITERARY CRITIC SLOBODAN JOVANOVIĆ AS A WRITER OF THE HISTORY OF SERBIAN CULTURE
}

Summary

In the polyhistorical work of Slobodan Jovanović, his works from the field of literary criticism, with which he actually entered the public life of Serbian culture, occupy a somewhat marginalized, but not unimportant place. In Collected Works (1990-1991), literary criticism and reviews were published in the 11th and 12th volumes. As a literary critic, Slobodan Jovanović always pays attention to the wider cultural-historical context of a literary work. Even when he turns to immanent analysis, he tries to make such an examination a function of researching the cultural mission that the work potentially accomplishes. His critique is marked by a kind of cultural enlightenment, which emphasizes the somewhat utilitarian nature of literature as a spiritual field in which broader goals are to be achieved. And when, from today's point of view, he underestimated the importance of some creators, it was never because of personal idiosyncrasies, but because his scientific habitus took into account the representation of culture in the historical context. Written in an extremely clear and understandable, Belgrade style, of which he is one of the founders, his literary critiques can thus, in accordance with modern methodological starting points of the poetics of culture, be considered as a fragmentary contributions to the history of Serbian culture. 